\title{
THE REVIVALISM OF VEILED FEMALE STUDENTS: An Account of Their Views of Democracy in Indonesia
}

\author{
Iswahyudi \\ State Institute of Islamic Studies Ponorogo, Indonesia \\ E-mail: iswahyudi@iainponorogo.ac.id \\ Udin Safala \\ State Institute of Islamic Studies Ponorogo, Indonesia \\ E-mail: udinsafala9@gmail.com \\ Umi Kulsum \\ State Institute of Islamic Studies Ponorogo, Indonesia \\ E-mail: umikulsum@iainponorogo.ac.id
}

\begin{abstract}
The issue of veiled female students has become a polemic, especially among the State Islamic Religious Colleges (PTKIN) in Indonesia. This is because female students wearing veils obstructs the learning activities and is also viewed as a sign of Islamic revivalism. Although this revivalism is considered as a barrier to the Islamic moderatism promulgated by the state and PTKIN, excessive concern about it is not always true. Azyumardi Azra once argued that revivalism does not always lead to radicalism and destruction and also referred to it as "inward-oriented" revivalism, which is a form of personal religiosity while practicing and living according to Islam. This article attempts to examine the revivalism of veiled female students based on their views of democracy in Indonesia. By employing the phenomenological approach, this study discovered that these students hold positive views of democracy as a means of societal welfare creation in Indonesia. However, they asserted that this democracy should be rejuvenated as it is not only a concept but also a practical matter, which must be present in the realities of the Indonesian people. Consequently, this view demonstrates inward-oriented revivalism, not a radical and destructive one.
\end{abstract}

Keywords: Democracy; Revivalism; Veiled Female Students; PTKIN. 


\section{Introduction}

In February 2018, Indonesia was frowned upon by a polemic on the prohibition of wearing veils for female students by the State Islamic University (UIN) Sunan Kalijaga Yogyakarta. The ban was issued by the Chancellor Yudian Wahyudi with letter number B1031/Un.02/R/AK.00.3/02/2018. One reason for the ban is that wearing the facial veil is not by the vision of moderate Indonesian Islam. ${ }^{1}$

UIN Sunan Kalijaga is not the first university to ban the use of veils on campus. At least, there are six universities that have carried out the ban. First, on September 22, 2013, the Advanced Indonesian College of Health Sciences (STIKIM), Jakarta, issued Sumayyah for wearing a facial veil. Second, on the steps of March 26, 2015, Lambung Mangkurat University (Unlam), Banjarmasin forbade female students from wearing the facial veil because it could interfere with the teaching and learning process. Third, in April 2017, the State Islamic Institute of Jember (IAIN) banned the use of the veil because it does not reflect a friendly and soothing Islam. Fourth, on July 7, 2017 Unpam campus, the city of South Tangerang forbade female students from wearing the facial veil and the prohibition of having long hair for students because it could interfere with the teaching and learning process. Fifth, IAIN Bukit Tinggi deactivates Dr. Hayati Syafri, an English lecturer at the Faculty of Tarbiyah and Teacher Training for wearing the facial veil. ${ }^{2}$ Sixth, as in Bukit Tinggi, the dismissal of teaching staff, Dr. Hayati Syafri was also carried out by the Jakarta Islamic State University (UIN) for wearing a facial veil. ${ }^{3}$

The ban on facial veils for female college students, especially Islamic religious universities such as UIN, IAIN, and STAIN, is understandable. First, the Indonesian Institute of Sciences Research (LIPI), for example, released a report that radical understanding had infiltrated into five well-known state universities. More than that, there are 86 percent of the total number of students in Java rejecting the ideology of Pancasila and want the implementation of Islamic

\footnotetext{
1 "Apakah Pakai Cadar di Universitas Perlu Dilarang" in http://theconversation .com/

2 “Tidak hanya Unpam Inilah Kampus-kampus yang Melarang Mahasiswi Bercadar" in https://www.kiblat.net/2017/08/08.

3 "Polemik Larangan Pakai Cadar di Kampus Perlu Segera Diakhiri" in http://kabar24.bisnis.com/read/20180315/255/750127.
} 
law. ${ }^{4}$ Second, the veil is a symbol of one's diversity. The facial veil as a symbol can be an identity for a school or group. Following Clifford Geertz, the veil is a model of reality. ${ }^{5}$ The veil describes the transcendent world (model for reality), which is a reference for the veiled activity. Religion in the veil symbol system is always closely related to the social reality that surrounds and the psychological condition of the religious community ${ }^{6}$ or the wearer of the facial veil. The model for reality, which is the basis of veiled actions, is, therefore, identified as an exclusive and textualist pattern of religiosity, a pattern that Marty calls fundamentalist because he does not see religion from its sociological side and traces its historical. ${ }^{7}$ Third, the facial veil has become a negative label for the identity of certain ideological movements, which are enemies of the diversity and nationality of Indonesia. On the other hand, Islamic tertiary institutions such as UIN, IAIN, and STAIN are ideological institutions for the continuity of diversity and nationality in Indonesia. The wearing of the facial veil is a symbol of Islamic revivalism. John L. Esposito marked the revivalist group as a group that interpreted the Qur'ān literally, statically, and extremely. ${ }^{8}$ In Indonesia, the land for Islamic revivalism is carried out, including through universities in addition to mosques and boarding schools.

However, revivalism is not singular. Revivalism can come from increasing one's religiosity and can also be caused by monolithic understanding. This paper, therefore, will show the revivalism of facial veil students based on their views on democracy. This, as Azra

${ }^{4}$ lipi.go.id, 19/2/2016.

5 Clifford Geertz, Kebudayaan dan Agama, trans. Francisco Budi Hardiman (Yogyakarta: Kanisius, 1992), 7-9; Nur Syam, Madz̧ab-Mad₹̧ab Antropologi (Yogyakarta: LKiS and IAIN Sunan Ampel, 2009), 92; Hadziq, Islam dan Budaya Lokal: Belajar Memahami Realitas Agama dalam Masyarakat (Yogyakarta: TERAS, 2009), 45.

${ }^{6}$ Lukman Hakim, "Kritik dan Apresiasi terhadap Peradaban Islam Nusantara", in Abdul Hakim and Yudi Latif (eds.), Bayang-bayang Fanatisme: Esai-esai untuk Mengenang Nurcholish Madjid (Jakarta Selatan: Universitas Paramadina and Pusat Studi Islam dan Kenegaraan, 2007), 123.

${ }^{7}$ Martin E Marty, "What is Fundamentalism? Theological Perspective" in Kung and Moltmann (eds.), Fundamentalism as a Ecunemical Challenge (London: Rouledge, 1992), 3-13.

8 John L. Esposito, Islam: the Straght Path (Oxford: Oxford University Press, 1988), 27.

9 See fuller in M. Imdaddun Rahmat, Arus Baru Islam Radikal: Transmisi Revivalisme Islam Timur Tengah ke Indonesia (Jakarta: Erlangga, 2009). 
said, revivalism does not have to be destructive because it is a mere form of religious practice. Azra calls this revivalism orientation inward-oriented. Conversely, if revivalism is destructive and presents intolerant diversity, he calls it revivalism in the outward-oriented category. ${ }^{10}$

Democracy was chosen as the focus of the study for several reasons. First, democracy as Nafi 'Muthohirin's research is included as a central issue to see a group referred to as fundamentalist or not. ${ }^{11}$ Second, democracy, as revealed by Sadek Jawel Sulaiman, is a nursery for other ideas that accompany such freedom and others. ${ }^{12}$ Third, one's view of democracy can lead to a thesis of whether a person can be classified as a pro-Indonesian nationality or not.

The method used to express their views on democracy is a phenomenological method, which is a research method that seeks to uncover the social and cultural meaning of a group, in this case a veiled female student group. Because the phenomenological method requires researchers to be immersed with the subjects studied so that they appear to be culturally integrated, then in collecting data, researchers are assisted by female co-researchers to produce something clear and uncovered, so the data is original and not manipulative. The subjects of this study were facial veil female students at IAIN Ponorogo, amounting to five people with a composition of three female students of the Faculty of Ushuluddin Adab and Da'wah (FUAD) and two female students from the Faculty of Islamic Studies and Islamic Studies (FATIK).

\section{Revivalism of Students and Democracy \\ 1. Revivalism: A Response}

Fazlur Rahman asserted that revivalism is part of the religious dynamics of Muslims. According to him, the development of Islamic diversity was divided into four stages, namely: 1) the stage of revivalism that occurred in the late $18^{\text {th }}$ and $19^{\text {th }}$ centuries. Islamic revivalism was marked by the Wahabiyah movement in Saudi Arabia, Sanusiyah in North Africa, and Fulaniyah in West Africa; 2) the modernist stage which emerged in the early $19^{\text {th }}$ century. The

10 Azyumardi Azra, Pergolakan Politik Islam (Jakarta: Paramadina, 1996), 107-108.

11 Nafi' Muthohirin, Fundamentalisme Islam: Gerakan dan Tipologi Pemikiran Aktivis Dakwah Kampus (Jakarta: IndoStrategi, 2014), 207.

12 Sadek Jawad Sulaiman, "Demokrasi dan Syura" in Wacana Islam Liberal: Pemikiran Islam Kontemporer tentang Isu-Isu Global (Jakarta: Paramadina, 2003), 125. 
modernist stage was initiated by Sayyid Ahmad Khan in India, Jamaluddin al-Afghani in the Middle East, Muhammad Abduh in Egypt, 3) Neorevivalists, namely resistance to the modernist group. Revivalism was spearheaded by al-Mududi in Pakistan; 4) the neomodernist stage which for Rahman as a possible stage for the Islamic renaissance. Rahman calls himself a neomodernist group with a pattern of merging between modern rationality with classical Islamic teachings. ${ }^{13}$ For Rahman, both revivalism and modernism refer to the same spirit, namely resistance to external aspects that are considered non-Islamic.

Rahman acknowledged that revivalism was present as a reaction to modernization. Revivalism, in this case, is equated with fundamentalism. ${ }^{14}$ Modernization is an era produced by the West with an emphasis on rationalization. This means that modernization will result in the existence of Islam, which is often non-rational. Through modernization, the West is able to control the Islamic world through industrialization, democracy, secularization, market economics, and others. ${ }^{15}$ Modernization has raised his awareness. However, the response to modernity is not uniform. Ma'an Ziyadah, as quoted by $\mathrm{Al}-$ Zastrouw $\mathrm{Ng}$, portrayed the diversity of responses to modernity in three attitudes. First, to be extreme, namely rejecting all things that smelled of the West while laughing at something apologetic that Islam has been self-sufficient for the problem at hand. Second, accept Western civilization without reserve. For them, the West overcomes all problems. Third, the merging of Western thought with the repertoire of Muslims. The West and Islam are looking for positive elements and filtering out something of negative value. ${ }^{16}$

Revivalism or fundamentalism is a response to the extreme attitude towards the West in the Ma'an Ziyadah category above. John L. Esposito mentions groups that are considered literalist, extreme, and static in interpreting the Scriptures as a revivalist group, a group that often presents Islamic political movements. As a result, Islamic

\footnotetext{
13 Gregory J. Barton, Modernisme Nurcholish Madjid, Djohan Effendi, Ahmad Wabib, dan Abdurrabman Wabid, trans. Nanang Tahqiq (Jakarta: Paramadina, Pustaka Antara, Yayasan Adikarya IKAPI, and The Ford Foundation, 1999), 9.

14 Syarif Hidayatullah, Intelektualisme dalam Perspektif Neo-Modernisme (Yogyakarta: Tiara Wacana, 2000), 47.

15 Al-Zastrouw Ng, Gerakan Islam Simbolik: Politik Kepentingan FPI (Yogyakarta: LKIS, 2006), 22-24.

16 Ibid., 25-26.
} 
revivalism is labeled as an intolerant and violent movement. ${ }^{17}$ For Esposito, the revivalism movement is increasing in many Muslimpopulated countries due to the desire to return to the greatness of Muslims under the umbrella of the Khilafah. ${ }^{18}$

Although revivalism or fundamentalism is pejorative, Azra sees it in a different position. According to him, revivalism can mean an attitude of religious practice that is inward (inward oriented) and more spiritual. This "inward" revivalism emphasizes individual piety and does not affect the surrounding social sphere in the sense of being constrained by that piety. The dangerous attitude of revivalism is in the sense of "outward-oriented". His devotion to religion causes intolerant and extreme religious extremism. ${ }^{19}$

\section{Student Revivalism in Higher Education (Campus)}

Campus becomes an alternative spreading of the idea of revivalism starting from the figure of Muhammad Natsir. ${ }^{20}$ Natsir has a desire to make the Indonesian state an Islamic state. After his efforts failed through the Masyumi party, Natsir initiated the formation of the Indonesian Islamic Da'wah Council (DDII) in 1967. Among Natsir's efforts in developing DDII was. First, sending Indonesian students to the Middle East at a cost from Saudi Arabia. After returning from the Middle East, students become ideological cadres of DDII. Second, DDII translates various works of transnational figures who become "mandatory books" of revivalism movements such as the work of Hasan al-Bannā, 'Abd Allāh b. Bāz, Abū al-A'lā al-Mawdudī, and others. For development, DDII carried out a structured movement in three facilities, namely pesantren, campus, and mosque. Pesantren that emerged from this movement are Pesantren Minhajus Sunnah Bogor, Nida'ul Islam Foundation, Jakarta As-Sofwah Foundation, and Pesantren Al-Irsyad Tengaran Salatiga. While the campus area movement is usually combined with

\footnotetext{
17 Esposito, Islam: the Straght Path, 27.

18 Muthohirin, Fundamentalisme Islam, 48-49.

${ }_{19}$ Azra, Pergolakan Politik Islam, 107-108.

${ }_{20}$ Muhammad Natsir was born on July 17, 1908 in Alahan Panjang, West Sumatra. Natsir was one of the Minangkabau crew members who was the founding father of the Indonesian nation. Natsir was an Islamic fighter and always argued with Sukarno about the idea of an Islamic state. Khalid O. Santosa (ed.), "sebuah pengantar" in Mohammad Natsir, Islam sebagai Dasar Negara (Bandung: Sega Arsy, 2004), 1-3.
} 
the realm of the mosque on the campus. The trick is to establish Lembaga Dakwah Kampus (a campus missionary network). ${ }^{21}$ Public and large campuses such as the Salman ITB mosque, the Saladin mosque at UGM, and others are examples. In campus mosques, Islamic basic studies (monotheism) and war of thought (gharw al-fikr) are carried out. ${ }^{22}$

Muthohirin, with a copy of the University of Indonesia, called the campus as a place for students to be in the vortex of social change. The students, finally, participated in various intra-campus and extra-campus organizations, ranging from the left, moderate to the right. ${ }^{23}$ Each contesting organization competes for members of students. Each organization also offers a social "engineering" that is envisioned to be fought for.

The enthusiasm of student activism, on the one hand, and the lack of understanding of religion on the other is a gap for revivalism. The campus is not a boarding school with the learning of assistive sciences that are well established in understanding religion. The revivalism movement offers religious knowledge that is instant and easy to understand, but devoid of dialectics. The knowledge acquired, consequently, is monolithic and rigid. Following Peter L. Berger, ${ }^{24}$ the monolithic construction of religious scholarship was internalized by agents of revivalism so that it was objectified in students. Veiled activism or symbolic religious activism, is part of the externalization carried out after the objectification process is strong.

Initially, the revivalist movement had not yet entered the State Islamic Religious University (PTKIN). This is caused by several factors. First, many PTKIN students are pesantren alumni. They already have, following Heidegger, a strong religious basis, the fore structure of understanding, ${ }^{25}$ making it difficult to get a new understanding of infiltration. Second, the dense religious curriculum

21 About the DDII movement and its transformation into a radical Islamic movement in Indonesia and the frictions that occur in it can be read in full in Rahmat, Arus Baru Islam Radikal.

${ }^{22}$ Yudi Latif, Intelegensia Muslim dan Kuasa Geneologi Intelegensia Muslim Indonesia Abad ke-20 (Bandung: Mizan, 2005), 532.

23 Muthohirin, Fundamentalisme Islam, 78-81.

24 Peter L. Berger, Langit Suci: Agama sebagai Realitas Sosial (Jakarta: LP3ES, 1991), 45.

${ }^{25}$ Richard E. Palmer, Hermeneutics (Evanston: Northwestern University Press, 1969), 130-131. 
content causes students to gain religious knowledge holistically. Third, the teaching staff or lecturers have strong religious qualifications and understanding of various established religious references so that they can be filtering power for a new understanding of students.

However, with the expansion of the scope of the study area of the State Islamic University (PTKIN) from the State Islamic University (STAIN) to the State Islamic Institute (IAIN) or from IAIN to the State Islamic University (UIN) has the following implications. First, the opening of general science-based study programs such as Tadris Science, Tadris English, Tadris Mathematics, Islamic Communication and Broadcasting (KPI), and others as well as medical faculties. Second, due to the opening of study programs and general faculties, it has implications for the recruitment of lecturers not only from non-pesantren (do not understand religion well), but also from alumni of general tertiary institutions, which in certain cases, are alumni from the network of revivalist groups. Islamic student. Third, another result is that, in addition to lecturer recruitment, students who register with PTKIN are also increasingly diverse from various schools, including public schools that do not have a concentration in the religious field. Fourth, new study programs or new faculties must adapt to study programs or faculties in general tertiary institutions with the application of measured competencies. As a result, to fulfill this competency, religious curriculum-based content is reduced. The students, finally, sought religious knowledge outside of lectures.

This condition was also experienced by Ponorogo State Islamic Institute (IAIN). IAIN Ponorogo had changed its status from the State Islamic High School (STAIN) to IAIN in $2017 .{ }^{26}$ IAIN Ponorogo has a total of 20 study programs with details of 16 study programs for S1 and 4 for S2 study programs. The study program that was opened was not purely a religious-based. The study programs are the English Tadris Study Program, the Natural Science Tadris Study Program (IPA), the Social Sciences Tadris Study Program (IPS), and the Islamic Communication and Broadcasting Study Program (IPS). This Study Program attracted the interest of many from public schools such as high school and vocational school. The Islamic Communication and Broadcasting Study Program (KPI), for example,

26 See Presidential Regulation Number 75 of 2016. 
in 2018, received nine high school alumni, 13 vocational high school alumni, and $98 \mathrm{MA}$ students from the MA. ${ }^{27}$

As a result of the opening of the new student admission system and the variety of study, programs offered opened the revivalism faucet such as the use of religious symbols in the Ponorogo IAIN environment, in this case, the use of the facial veil. Based on preliminary research, at IAIN Ponorogo, there have been around five veiled female students consisting of three female students of the Ushuluddin Adab and Da'wah Faculty (FUAD) and two female students from the Faculty of Islamic Studies and Islamic Studies (FATIK). The use of IAIN Ponorogo female facial veils is known to experience a growing number. This is evident, for example, at the beginning of the entry, especially during the Introduction to Academic and Student Culture in 2018/2019, only one person dared to reveal their identity. After passing a few semesters, the use of the facial veil is increasing. ${ }^{28}$ This increase can be caused by the infiltration of religious understanding to female students or also by seeing the situation of development and regulation at IAIN Ponorogo after previously as the user of the symbol.

The inclusion of Islamic revivalism among State Islamic Religious Colleges (PTKIN), including IAIN Ponorogo, can be described as follows.

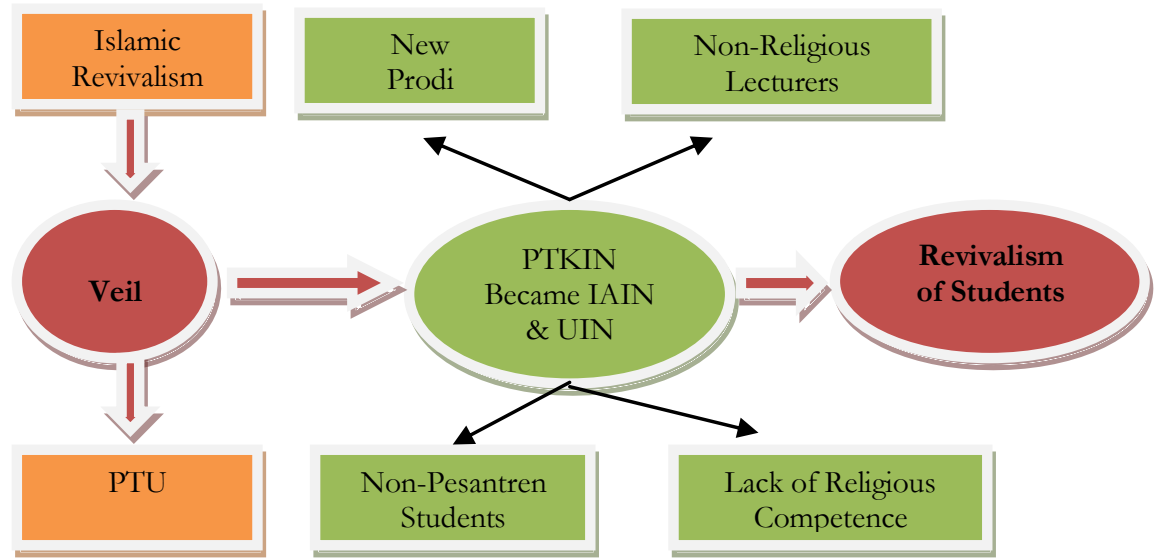

27 Data were obtained from the administration of the Faculty of Usuluddin Adab and Da'wah on December 22, 2018.

28 PBAK observations in 2018/2019 on 09 to 16 August 2018. 


\section{Democracy: Concepts and Conflicts}

Affan Gaffar gives two meanings in democracy, namely normative meanings and empirical meanings. Democracy in the normative sense is an ideal democracy that is intended to be carried out by a country. Whereas democracy in an empirical sense is democracy in the world of practical politics. For Gaffar, democracy contains both theoretical concepts and practical experience. In line with Gaffar, Joseph A. Schmeter explained that democracy contains institutional planning to reach political decisions. ${ }^{29}$

Sadek Jawel Sulaiman explained that there were at least seven characteristics of the democratic system. 1) freedom of opinion both in the public domain and against the authorities; 2) the existence of a free system of government with free choices as well; 3) the recognition of majority rule and the recognition of minority rights; 4) there is the view that political parties play an important role as the aspirations and hopes of the community towards government; 5) the separation of powers between the legislative, executive and judiciary; 6) constitutional orientation; and 7) freedom to act. ${ }^{30}$

Even so, not all Muslim intellectuals agree on democracy when faced with Islam. At a minimum, Muslim intellectuals are divided into three groups. First, democracy and Islam are two opposites. Islam is an independent system (self-sufficient). The relationship between the two is mutually exclusive (mutually exclusive). The rules in society are governed by Islam and not by a democratic system. Intellectuals such as Sayyid Qutb, Fadhallah Nuri, Muhammad Husain Thabathabai, Muhammad Mutawalli al-Sha'rawi, and Abu Bakar Baasyir are supporters of this contradictory idea. ${ }^{31}$ Second, democracy can be by Islam if democracy is interpreted substantially as an effort to achieve justice, a prosperous society and so on, but Islam is not by democracy if what is meant is democracy in the procedural sense such as the formation of law by the legislature and others. This group was driven by intellectuals such as Abū al-A'lā al-Mawdudī, Rashid alGhanaoushi, Abdul Fattah Morou, Taufiq Asy-Syawi, and Moh. Natsir. Third, democracy and Islam go hand in hand as practiced by the West. This is because Islam is a democratic religion. In Islam

29 A. Ubaidillah and Abdul Rozak (eds.), Demokrasi, Hak Asasi Manusia, dan Masyarakat Madani (Jakarta: ICCE UIN Syarif, 2006), 131.

30 Sulaiman, "Demokrasi dan Syura", 126-127.

31 Ubaidillah and Rozak (eds.), Demokrasi, Hak Asasi Manusia, 158. 
there is the principle of shüra (deliberation) as well as the concept of ijtibäd and ijmă or community consensus. According to R. William Liddle, Indonesian people in practice follow this third group. Intellectual supporters of this idea are like Fahmī Huwaydī, Abbas Maḥmūd al-'Aqqād, Jamāl al-Dīn al-Afghānī, Nurcholish Madjid, A. Syafii Maarif, and Gus Dur. ${ }^{32}$

\section{Democracy in the Scrolling Students 'Views}

This section will describe the views of IAIN Ponorogo students in three aspects, namely their views on democracy, their criticism of democracy in Indonesia, and what should be done to democracy in Indonesia, whether reconstruction or deconstruction.

\section{Concept of Democracy}

All female students wearing facial veils have a positive view of democracy. None of them questioned the concept of democracy. Their positive outlook was probably due to their knowledge of democracy learned in the Civic Education course in the early semester. Every study program at IAIN Ponorogo is required to include Pancasila and Civic Education courses. These two courses provide knowledge to students about state ideology which includes the history, philosophy, and perspectives of the Pancasila on the national system and the state system. ${ }^{33}$ Civic Education transforms three things, namely civic knowledge, civic disposition, and civic skills. Civic knowledge is the knowledge of students about their rights and obligations as citizens. This is an aspect of concept or theory about citizens. Civic knowledge is then strengthened by Civic

\footnotetext{
32 Ibid., 159.

33 It must be distinguished between "nation" and "state". Nation is a group of people who are bound by similarities so that they become an inseparable part. Nations are like tribal ties, language ties, racial ties and others. Indonesia is a country with very many nations. While the state is an organization that covers the nation in achieving its goals, namely independence, prosperity, prosperity, justice, tranquility, law enforcement and others. Indonesia is a country with various nations. This means various differences agree and make agreements to be together, minimize differences and work for the common good. The agreement then formed a country called Indonesia. Therefore, binding and defending the nation is very important. When the nation is torn apart, the country's buildings are torn apart. The form of the state may change as long as the nation remains intact. Strong Bangas can lead to a strong country. Conversely a weak nation makes the country also weak.
} 
Disposition, which is the attitude or feeling of citizens. This is the area of taste or heart. Civic Disposition, therefore, talks about one's commitment to citizenship in terms of gender justice, diversity, pluralism, upholding human rights, democratic attitudes, and others. While the Civic Skill is a real act of someone in building a civilized society with real and practical behaviors in life, such as respecting differences, acting arbitrarily, critical of unjust government actions, controlling government policies, and others. ${ }^{34}$

a. Democracy: Equal Rights

For Haza, one of the facial veil female students of the KPI Study Program, Democracy is a form of government with a sign that all citizens have the same equal rights, including decision making. Haza said.

Democracy is a government in which all people or citizens alike have the same rights in various ways, including in deciding something. There is no priority over others. All people are equal before the law. Rich people and officials who are guilty are punished with ordinary people. If people are poor, because a chicken thief is punished, and the corruptor is free, it means leaving democracy. Democracy means the same, the same rights, and the same in carrying out their obligations. ${ }^{35}$

The balance between rights and obligations, for Nurcholish Madjid is a "middle way", an attitude that should be done by humans. God has conveyed this middle ground continuously. "Middle way" (wasat) and fair (qist). The implementation of rights and obligations is part of God's direction so that humans live in balance, the balance between rights and obligations. ${ }^{36}$ Haza's statement was reinforced by Avana, a veiled student from the BPI study program, as follows.

Democracy is equality in society. People get the same rights before the law. Small people and big people alike get service. Democracy is a system of rights and obligations carried out without impartiality. Sumatran people get the same access as Javanese in development. If the roads in Java are good, then outside Java, Sumatra, Sulawesi, and others must be the same. If it's not the same, it means our country is not democratic. ${ }^{37}$

\footnotetext{
34 Ubaidillah dan Rozak (eds.), Demokrasi, Hak Asasi Manusia, 10.

35 Interview with Haza, on Tuesday, 12 November 2019 at 10:00 a.m.

36 Nurcholish Madjid, Cendekiawan dan Religiusitas Masyarakat (Jakarta Selatan: Paramadina and Dian Rakyat, 2009), 118.

${ }^{37}$ Interview with Avana on Wednesday, November 13, 2019 at 12:00 noon.
} 
Avana, as Haza, stresses the similarity in accepting the results of the implementation of democracy as a result of development. Haza, through this statement, wants democracy not only in the sense of democratic procedures carried out like the General Election but wants a substantial democracy. The hope of this substantive democracy following Avana's view is that there is equitable development for all regions in Indonesia. Sumatra is the same as Java and others. Avana's hopes are similar to those of many people from various countries choosing democracy. In 1990 the Center for Islamic Studies and Society of IAIN Jakarta (now UIN Jakarta) once released the choice of Indonesian people on a democratic system to be applied at around $84 \%$. This means that most Indonesians choose democracy because they hope for a substantial democracy. Support for democracy is also carried out by people in developed countries such as the United States supports $88 \%$ democracy, South Africa supports $85 \%$, Japan supports democracy by $88 \%$, Turkey supports $89 \%$. Support for democracy is also given by citizens such as South Korea, Russia, Mexico, Brazil, and others, even though the portion is lower than Indonesia. ${ }^{38}$

\section{b. Democracy: Deliberation}

Almost all facial veil female students answered that deliberation was part of Islamic practice. Deliberation is mentioned in the Qur'ān in several places. Deliberation for veiled female students is an implementation of democratic practices as well. Through this deliberation, the veiled female students agreed that democracy is in the scriptures. Avana firmly said.

Democracy is deliberation. The Qur'ān explains a lot about deliberation, as found in the letter Âli 'Imrān, what verse is forgotten, but it is there. With deliberation, we can understand the opinions of others, and not our opinions must be accepted. We deliberately learn to accept other people's opinions and be ready to accept defeat. Democracy is ready to accept defeat. ${ }^{39}$ Besides Avana, Vera emphasized what was said by Avana. Democracy exists as described in the Qur'ann, which explains the principles of democracy. This principle is in Âli 'Imrān verse 159; al-Syūrā verse 15 . Honestly, there are still many other verses about justice, defending humans and others; for me, those verses

\footnotetext{
38 Zuly Qodir, Sosiologi Politik Islam: Kontestasi Islam Politik dan Demokerasi di Indonesia (Yogyakarta: Pustaka Pelajar, 2012), 172-173.

${ }^{39}$ Interview with Avana on Wednesday, November 13, 2019 at 12:00 noon
} 
are elements of democracy. Only whether the verse has been practiced or not is another matter. Wong is still a lot of corruption; there are still lots of unfair laws. ${ }^{40}$

What Avana and Vera said was not wrong. Proponents of democracy take one of the practices taught by the Qur'ān, namely, deliberation is considered as the support of the holy book for democracy. Muhammad Sa ${ }^{\top} \overline{1} \mathrm{~d}$ al-Ashmāwī explicitly called the concept of shīra the most appropriate concept to explain about democracy. In one verse 159 of the letter Âli 'Imrān, Allah ordered the Prophet Muhammad to consult with the leaders of the Muslims. "And consult with them in various affairs. If you have a strong aspiration to do something, then put your trust in Allah." ${ }^{41}$ The tradition of deliberation is a custom of pre-Islamic Arab society. This tradition continued after the arrival of Islam. Al-Qur'ān documents this tradition in surah al-Shūrā [42]: 37 “... and if they disagree, they negotiate". Through deliberation and also other principles such as justice and egalitarianism, Robert N. Bellah and Gelner said that the leadership model of the Prophet Muhammad, when in Medina was glitter and participatory. Called by Bellah, egalitarianism and participation are too modern, not only modern, but too modern. Why can it be called modern? The answer is because the agreements made together represent the commitment and active participation of individuals involved in the political community in Medina. The political structure used at that time was classified as modern. This is because there is an open system. ${ }^{43}$

c. Democracy: Election (People's Choice)

Responding to the election as part of the implementation of people's power and sovereignty, Haza said.

In my opinion, the power of the people is there, but that power is based on the teachings ordered by Allah. So it is not arbitrary, not according to his own will, that power must be

\footnotetext{
40 Interview Results Thursday, October 24, 2019 at 13:00 p.m.

${ }^{41}$ Muhammad Said al-Ashmawi, "Islam dan Demokrasi", in Ulil Abshar Abdalla (ed.), Islam dan Barat: Demokrasi dalam Masyarakat Islam (Jakarta: Paramadina, 2002), 3.

42 Ibid., 4.

43 Bakhtiar Effendy, "Demokrasi dan Agama: Eksistensi Agama dalam Politik Indonesia", in Komaruddin Hidayat and Ahmad Gaus AF (eds.), Islam, Negara, dan Civil Society (Jakarta: Paramadina, 2005), 161.
} 
exercised based on the rules of Allah. If humans make rules, those rules cannot come out of the rules of Allah. ${ }^{44}$

Haza did not reject the existence of human power and sovereignty. Humans are free to regulate their lives with laws that are based on their benefits, only that freedom and sovereignty must not be arbitrary. Regulations and sovereignty or power must be based on the rules of Allah SWT and regulations made by the Prophet Muhammad. Haza, with this statement, indirectly recognizes democracy with an electoral system that is run. What Haza said, was almost the same as what Avana said. She said.

All power belongs to Allah. If there is people's power, it means that the people have the right to express their wishes so that their lives will be filled with justice, welfare, and so on. All systems in a decisive democracy are the people, then those who are elected are also the people, and in exercising power, the aim is for the people as well. Islamic democracy, in my opinion, the leader is elected by the people, but the leadership, its ruler is subject to sharia and is willing to do shürā as exemplified by the Prophet Muhammad. Shürā is how Rasulullah SAW used to mingle and solve community problems with his friends. ${ }^{45}$

Avana has a similarity to the idea with Haza that is not questioning democracy or elections conducted by the people. But for Avana a leader must obey or carry out the religious laws that Avana calls "submission to sharia". Avana does not specify the answers to what is called sharia. But if you look at the information afterward which is about shürä, what is meant by sharia is implementing the principles of democracy correctly. The principle of democracy is shürä or deliberation. Deliberation for Avana is a mechanism for taking the example of the Prophet Muhammad in making decisions. Avana wants to say that by Shariah-compliant, it is the fulfillment of several elements of deliberation among them as revealed by Nurcholish Madjid that there is wisdom. ${ }^{46}$

\footnotetext{
${ }^{44}$ Interview with Haza, on Tuesday, 12 November 2019 at 10:00 a.m.

${ }^{45}$ Interview with Avana on Wednesday, November 13, 2019 at 12:00 noon.

46 Nurcholish Madjid, Pintu-pintu Menuju Tuban (Jakarta Selatan: Paramadina and Dian Rakyat, 2008), 254.
} 


\section{Criticism of Indonesian Democracy}

The facial Veil female students have the view that democracy is permissible in Islam even with a variety of strict requirements such as a leader must carry out the commands of Allah, be fair, and be responsible. Democracy in Indonesia has not been running for a century. Democracy in Indonesia has experienced a long journey and is full of deviations and problems, starting with Parliamentary Democracy, Guided Democracy, Pancasila Democracy of the New Order, and now being tested, namely Democracy in the reformation period (from 1998 to present). As revealed by Nurcholish Madjid, democracy is not ready-made and ready-made item. Democracy is the learning and learning process. The process is endless. What Indonesia has done with various kinds of democracies is trials that may be wrong and may have benefits. ${ }^{47}$

a. Legal Stratification

Various deficiencies of democracy in Indonesia have been criticized by intellectuals; these criticisms are taken from various points of view. The strongest criticism is the criticism of the implementation of the law that has not gone well. The law does not yet uphold justice for all parties. When a prospective civil servant wants to apply for a job, it is required to request police information, but for former corruptors, it is still free to run for public office. Like these intellectuals, Haza, a veiled student from the KPI Study Program said.

If the drawbacks are like sometimes the sharp edges are often down, leaning upward. Chicken thieves are jailed, while corruptors are free to get facilities. If a poor person is guilty, he is quick to punish, but if a rich person has a position, the process official takes a long time. Then sometimes there are people fighting over power like that, there is still a lot of corruption, there is also political money. ${ }^{48}$

Avana answered the same thing as Haza. Avana said in terms of the weaknesses of democracy in Indonesia.

In my opinion, democracy in Indonesia still sides with the upper classes and does not pay much attention to low-income groups. This is caused by the behavior of superiors or officials. Where is the justice if the officials like this? The law is right, but

\footnotetext{
${ }^{47}$ Ubaidillah dan Rozak (eds.), Demokrasi, Hak Asasi Manusia, 136-137.

48 Interview with Haza, on Tuesday, 12 November 2019 at 10:00 a.m.
} 
legal actors or officials who carry it out not be trusted. Maybe, because the choice process used to be so difficult to be fair. ${ }^{49}$

Avana does not question democracy, but she questions policyholders or democratic actors themselves. Irwi's following statement reinforces Avana's statement.

The model of democracy and its principles in Indonesia is already good because its spirit is taken from the values of Islam and the spirit of Indonesian culture that is tolerant, likes to help, tepo seliro, courtesy, mutual respect, and others. Maybe what needs to be fixed is the people who manage the government. Democracy depends on who is managing it; not all managers are good. 50

However, in the concept of democracy, it is not in the sense that there should be no different treatment. If anyone demands differences, the application of differences is permitted. Small children, for example, cannot be witnesses. Likewise, children themselves cannot be witnesses in their father's case. The problem of witnessing adultery for example requires four male witnesses (one is not enough). As long as the legal rationality and objectives of the law (maqạsid alshari $^{-} a$ ) can be explained, then the difference is precisely to support and strengthen legal justice. In a democracy, therefore, between similarities and differences can be divided into several categories, namely the same treatment for those who are the same; applying differences for those who are different and not applying differences for those who are different is caused by irrational reasons. ${ }^{51}$

b. Corruption and Money Politics

Corruption is not a matter of democracy specifically, including money politics. Corruption and money politics are problems of all government systems. Kartini Kartono, as quoted by Ubaidillah, Rozak et al., explained as an individual act of using authority or position to obtain personal gain. As a result of this action, it has been detrimental to the public, community, and state interests. ${ }^{52}$ Whereas what is meant by money politics or money politics according to Law No. 3 of 1999 article 73, paragraph 3 is giving someone to another person as part of a bribe so that the other person does not exercise his right to choose

\footnotetext{
49 Interview with Avana on Wednesday, November 13, 2019 at 12:00 noon.

${ }^{50}$ Interview with Irwi on Friday, October 18, 2019 at 13:30 p.m.

${ }^{51}$ Munir Fuady, Konsep Negara Demokrasi (Jakarta: Refika Aditama, 2010), 49.

52 Ubaidillah dan Rozak (eds.), Demokrasi, Hak Asasi Manusia, 233.
} 
certain choices. The gift can also be to make others do their rights in a certain way.

Ameda questions the following practices in a democratic country.

I wonder why in Indonesia, corruption is constantly being carried out. There is no law that given up in Indonesia. He said democracy was marked by the rule of law, a clean state and a country free of corruption. How did it turn out? If this continues, do not blame, there is another system that you want to try. Corruption does come together like it was in the poor you know. ${ }^{53}$

For Irwi, corruption begins with the practice of money politics. Money politics makes political practice expensive. The high cost of political practice makes the perpetrators intend to return the modality after he has authority. Irwi calls money politics the Javanese term "Nyogok". Irwi said. Nyogok is a Javanese term to refer to someone giving something to others so that their desires are achieved. In order for the regional legislative candidate to win, they gave money to several people to vote for him. The person who receives the money finally has a moral obligation to choose the giver of the money. The nyogok causes the adage of "ra duwe duwet ajo macung", it means do not have money, do not run for legislative membership. Irwi said.

Nyogok are almost done by people who will run for the Council.

Nyogok causes people to lose a lot of money. It can sell gardens, debt, or be financed by people. They must return the money they borrowed and so on. Five years' salary is not enough. Practically it is corruption. They were indeed chosen directly by the community, but their choice was due to the bribe. This is what is democratic. I don't take the money, but I don't vote. ${ }^{54}$

Nyogok must be recognized as a phenomenon that can be witnessed by anyone in Indonesia. As part of the drive for corruption, bribery is prohibited. In religion, it is called rishwah. Rishwah was threatened by God as an act that caused the culprit to go to hell, not only for bribe givers but for bribe recipients. Why go to hell? Because the culprit is cursed by Allah. Not only the perpetrator and the recipient, but the link between the two is also cursed. The danger of bribery was also revealed by Haza.

\footnotetext{
${ }^{53}$ Interview with Ameda on Thursday, November 15, 2019 at 11:30 a.m.

${ }^{54}$ Interview with Irwi on Friday, October 18, 2019 at 13:30 p.m.
} 
Giving money during elections is prohibited by religion. Its name is Rishwah. The culprits go to hell, you know. As a result of "serangan fajar" sorry for not having money. He can lose. But the one who wins just keeps silent. It's difficult if you win, there will be an attempt to return the duwit issued. How do you do that, among others, if you become an official, you want to accept bribes or commit corruption. That is, why sometimes buildings or roads are easily damaged, maybe the price is inflated. Later, cooperation with shops and others. ${ }^{55}$

Both Irwi and Haza mention the successive consequences of money politics, which is that first someone will look for capital, whether they are in debt, sell gardens, or other items or be funded by others. Second, he gave several people to choose himself. He is sometimes not alone, inviting the team. This team also gets a reward. As a result, the money spent increased. Third, it becomes what it wants. If it does not happen, some are stressed, some are bankrupt, and some are working as before. Fourth, when it becomes the desired position, it tries to return the issued capital. Fifth, look for ways to avoid being known by manipulating reports, manipulating budgets, and others. The opening door is money politics and the final door is corruption.

The way to avoid and prevent corrupt actions as said by Ubaidillah and Rozak is by the way the system works, and it cannot run alone. The work of the system involves many parties. Ubaidillah and Rozak mention the workings, as shown below. ${ }^{56}$

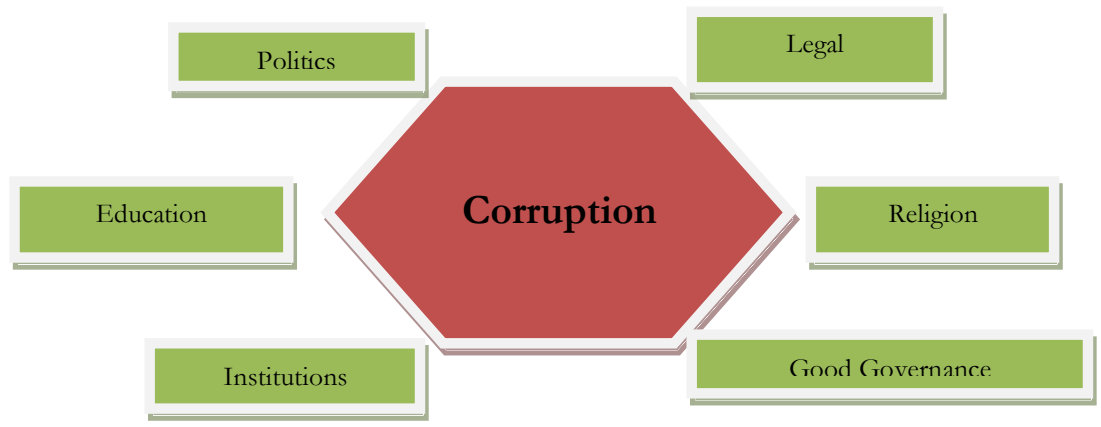

\footnotetext{
${ }^{55}$ Interview with Haza, on Tuesday, 12 November 2019 at 10:00 a.m.

56 Ubaidillah and Rozak (eds.), Demokrasi, Hak Asasi Manusia, 238.
} 
The picture above is a picture of how corruption is prevented. The explanation is as follows.

First, from the direction of political roles. The intention is the existence of a political will and political action from all parties. Second, legally, the intention is that handling corruption cases must have a high deterrent effect. It is said that the corruption of officials and authorities decreased in China because of the death penalty for corruptors. The same with China is South Korea. Countries like Singapore and Japan are countries with severe penalties. In Indonesia, severe punishment for corruptors still needs to be discussed. Capital punishment is still a polemic. The deterrent effect for an area, including Indonesia, is certainly different from other countries. Indonesia can be different from China, South Korea, Japan, Singapore, and others. The deterrent effect is based on the sociological, psychological, religious, and cultural considerations of Indonesia. As is known, Indonesia in 2018 is ranked 89 out of 180 countries in the Corruption Perception Index (CPI). For Southeast Asia, Singapore is the cleanest country, with Singapore being Brunei Darussalam, Malaysia, and Indonesia. From 2004 to 2019, there were at least 124 Regional Heads of corruption cases. ${ }^{57}$ Whereas in 2018, there were at least 454 problems to be prosecuted due to alleged corruption. While the number of mayors or regents in 2018 has also increased. ${ }^{58}$ Third, by establishing institutions that can sustain and support so that corruption does not occur and does not develop. Fourth, build a good and clean government. Fifth, give to all people about education that does not lead to corruption (anti-corruption education) or also called anti-corruption education. Sixth, instill a sense of self-religiosity. ${ }^{59}$

\section{Democracy: Continued or Replaced?}

The question in the subtitles above is an important question to find out the views of veiled students about democracy. Various criticisms given by female students veiled about corruption and also money politics, as well as the unfavorable journey of democracy in Indonesia (Guided Democracy, Pancasila Democracy and rising

57 "Naik 1 Poin Indeks Persepsi Korupsi Indonesia Naik ke Peringkat 4 di Asean" in databoks.katadata.co.id/datapublish/2019/01/29/diakses 19/10/2019.

58 "Berapa Jumlah Bupati Wali Kota yang Terjerat Kasus Korupsi" in databoks.katadata.co.id/datapublish/2019/10/09/Diakses 19/10/2019.

${ }^{59}$ Ubaidillah and Rozak (eds.), Demokrasi, Hak Asasi Manusia, 239. 
corruption in the Reformation era), did it cause the veiled students to want to replace other systems such as the Khilafah system or another. This question is fair to be expressed because criticism of democracy is not only an ontological problem of democracy itself but also axiological problems.

a. Repaired, not Replaced

The facial veil female students consider it unnecessary to replace democracy with another system. Enough with Pancasila (the five principles of Indonesia) only, practices that deviate from democracy need to be improved. Haza said.

Democracy must not be replaced. Just fix it. What needs to be improved is the power system. Many want to get power, but money is political, and then the law must be fair. Fix it to apply harsh penalties for corruptors, harsh punishments for time choice, public bribers, the law is not only for the poor but sharp up and sharp down. You are equally sharp. Just fix the system. Enough. ${ }^{60}$

What Haza said was also reinforced by Avana as follows. If you can continue, why replace it. Just repairing the wrong ones, the wrong systems, the fulfillment of human rights, the freedom of people to hold religious studies, spread religious teachings, and so on. If replaced, debates will arise, conflicts between Muslims, as well as people who agree and disagree. Indonesia is peaceful, peaceful, harmonious. Substitution causes harmony a problem. Indonesia should not be like other Islamic countries fighting with fellow Muslims and other people.

Haza and Avana agree that the defects of democracy must be corrected. Replacing democracy with other systems, as revealed Avana will present high social capital. Social capital can be in the form of disputes between citizens between those who agree with disagreeing. Disputes between citizens will be even more dangerous if religious arguments are included. What needs to be improved, according to Haza and Avana, is the problem of law enforcement, human rights enforcement, eradication of corruption, eliminating the practice of money politics. In general, Haza and Avana explained the improvement of the system. What they both say is that they want to restore democracy to the principles of the Qur'ann, especially the problem of the concept of the ummah. The concept of ummah has the following principles.

${ }^{60}$ Interview with Haza, on Tuesday, 12 November 2019 at 10:00 a.m. 


\begin{tabular}{|c|c|c|}
\hline No & $\begin{array}{c}\text { Ummat Principles } \\
\text { (Madani Community } \\
\text { Reflection) }\end{array}$ & Al-Qur'ān \\
\hline 1 & $\begin{array}{l}\text { Society complies with } \\
\text { rules }\end{array}$ & $\begin{array}{l}\text { Q.S. Luqmān [31]: 22, Q.S. Āli 'Imrān, } \\
\text { [3]: } 85 \text { and Q.S. al-Nahl [16]: } 36\end{array}$ \\
\hline 2 & Moderate community & $\begin{array}{l}\text { Q.S. al-Baqarah [2]: 143, } 251 \text { and Q.S. } \\
\text { al-Māidah [5]: } 66\end{array}$ \\
\hline 3 & Critical community & Q.S. Āli 'Imrān, [3]: 104, 110 \\
\hline 4 & Appreciation for plurality & $\begin{array}{l}\text { Q.S. al-Naḥl [16]: 93, Q.S. al-Māidah } \\
\text { [5]: } 48\end{array}$ \\
\hline 5 & Being religious society & $\begin{array}{l}\text { Q.S. Āli 'Imrān [3]: 113, Q.S. al-Naḥl, } \\
{[16]: 125}\end{array}$ \\
\hline 6 & Community justice & Q.S. al-A'rāf [7]: 159, 181 \\
\hline 7 & Temporal society & Q.S. al-A'rāf [7]: 34,Q.S. al-Hiijr [15]: 5 \\
\hline 8 & Responsible society & $\begin{array}{l}\text { Q.S. al-Baqarah [2]: 134, Q.S. Fușsilat, } \\
\text { [41]: } 40\end{array}$ \\
\hline
\end{tabular}

b. No Need of a Khilafah System

The Khilafah system became popular because it was developed by Hizb ut-Tahrir Indonesia (HTI). HTI, which has now been dissolved by the government through Perppu No. 2 of 2017 on Community Organizations, intends to make the Khilafah system a system that will unite Muslim countries as the caliphate of the past. The power of the past Muslim countries was very broad, from Morocco to the West, to an Eastern part of Indonesia, namely Merauke. For HTI, a country with such an area, it will be the richest country in the world as well as the biggest country. ${ }^{61}$ HTI is indeed against the democratic system practiced in Indonesia. HTI considers that democracy, as practiced in Indonesia, is by Islamic teachings. Democracy is a Western product. The rejection of the Khilafah system was carried out by Haza. He said

In my opinion, it's not Saudi Arabia or the Khilafah, but Pancasila is enough. There are points in it, and they must be applied as well. To stay prosperous. Because besides that in Indonesia, there is not only one religion, only Islam, but there are also Christians, Buddhists, Hindus, and others. So if it seems like the Khilafah system doesn't even fit, it is feared that there will even be an argument between religions. ${ }^{62}$

${ }^{61}$ HTI, Manifesto Hiz̧but Tahrir (n.p.: Hizbut Tahrir Indonesia, 2009), 60.

62 Interview with Haza, on Tuesday, 12 November 2019 at 10:00 a.m. 
Haza saw Indonesia as an independent system, by its history. Indonesia cannot be compared to Saudi Arabia or similar to other systems such as the Khilafah. Democracy is adapted to Indonesia, that's what was chosen. Haza's statement is reinforced by Avana as follows.

This country is enough to be itself because the state of a country with another is different. The democratic system has everything returned to the people, so the people must also be smart. If the current democratic system is in trouble, it is not the wrong system, but the people are wrong, so what must be done so that the next generation has morality, so that the democratic system will be straight and not straight out of the Islamic arena (with the guidance of al-Qur'ān and Hadìth). ${ }^{63}$

Like Avana, Vera also chose democracy. Vera said.

Indonesia is a democratic country, even though the majority is

Muslim and cannot be changed with any system. As citizens of

Indonesia, we must fight for the integrity of this nation, not to

let bad things into Indonesia. Given the struggle of the heroes

in liberating this country. Don't forget the history of the heroes

who, on behalf of Indonesia, made Pancasila a unifying tool for

the nation. Democracy has also been included in the fourth

Precepts. Democracy is under the umbrella of the Precepts. ${ }^{64}$

For Vera, democracy already has Islamic values. The fourth precept is both a symbol of democracy and a symbol of Islam because it teaches about wisdom and deliberation. Vera sees as said by the founders of the nation, that the Precepts in Pancasila apply hierarchically. The point is that the precept inspires and becomes the protector of the following precepts. Nurcholish mentions that the First Precept is a reflection of tawhid; The Second Precepts are a reflection of egalitarianism; The Third Precept is a reflection of the spirit of the Indonesian people who are aware of pluralism; The Fourth Precept is a symbol of deliberation; and the spirit of upholding justice is a reflection of the Fifth Precepts. ${ }^{65}$

\footnotetext{
${ }^{63}$ Interview with Avana on Wednesday, November 13, 2019 at 12:00 noon

${ }^{64}$ Results of an Interview with Vera on Friday, November 1, 2019 at 13:00 p.m.

${ }^{65}$ Nurcholish Madjid, Islam: Doktrin dan Peradaban: Sebuab Telaah Kritis tentang Masalah Keimanan, Kemanusiaan, dan Kemodernan (Jakarta: Paramadina, 2000), xcviii.
} 


\section{Concluding Remarks}

The facial veil female students do not want to change democracy into other systems, including the Khilafah. For them, Indonesia needs to be itself. What Indonesia needs is Muslims who not only know about Islam (having religion), but are also able to practice the teachings of known religions and feel the religion in their lives (being religious). Religion is not merely a cognitive aspect, but a religion that is lived, felt, and practiced. Aspects of democracy will be implemented in this religious being. This is what is called "realizing democracy". The benefits of religious democracy are first, it will accelerate the process of democratization from procedural democracy to substantial democracy. Second, the conceptions of democracy will be more resistant than the temptations of formality. Third, there is a motive that running democracy is part of practicing religion while opposing democratic principles such as justice, enriching oneself, money politics is against religion.

The view of realizing democracy does not show that the facial veil female students from IAIN Ponorogo experience a destructive orientation that negatively impacts others. Although this research does not elaborate on the reasons for facial veil actions by IAIN students, their view of democracy can be used as an initial hypothesis that revivalism carried out by them is inward-oriented from revivalism. They are not part of radical organizations and do not show a desire to establish a Khilafah state or an Islamic state in Indonesia. As an example of what Haza said, a facial veil female students from the Islamic Communication and Broadcasting Study Program (KPI) said that the use of the facial veil, she did it because she felt that he was imperfect, had a lot of sins. She wants to cover up the imperfection in terms of religion through facial veiling. ${ }^{66}$ Haza's statement, almost similar to Ameda, a facial veil female students from the Qur'an Study Program and the Interpretation that the beginning of wearing facial veils is a dream that continues about something that he interpreted as having to carry out Islamic sharia. She finally decided to wear the facial veil. When the facial veil is opened in front of men there is a feeling of insecurity and he feels something is missing in his life. The facial veil finally used until now. ${ }^{67}$

\footnotetext{
${ }^{66}$ Interview with Haza, on Tuesday, 12 November 2019 at 10:00 a.m.

${ }^{67}$ Interview with Ameda on Thursday, November 15, 2019 at 11:30 a.m.
} 


\section{Bibliography}

"Apakah Pakai Cadar di Universitas Perlu Dilarang" in http://theconversation .com/

"Berapa Jumlah Bupati Wali Kota yang Terjerat Kasus Korupsi" in databoks.katadata.co.id/datapublish/2019/10/09/Diakses 19/10/2019.

"Naik 1 Poin Indeks Persepsi Korupsi Indonesia Naik ke Peringkat 4 di Asean" in databoks.katadata.co.id/datapublish/2019/01/29 /diakses 19/10/2019.

"Polemik Larangan Pakai Cadar di Kampus Perlu Segera Diakhiri" in http://kabar24.bisnis.com/read/20180315/255/750127.

"Tidak hanya Unpam Inilah Kampus-kampus yang Melarang Mahasiswi Bercadar" in https://www.kiblat.net/2017/08/08.

al-Ashmawi, Muhammad Said. "Islam dan Demokrasi", in Ulil Abshar Abdalla (ed.), Islam dan Barat: Demokrasi dalam Masyarakat Islam. Jakarta: Paramadina, 2002.

Al-Zastrouw Ng, Gerakan Islam Simbolik: Politik Kepentingan FPI. Yogyakarta: LKIS, 2006.

Azra, Azyumardi. Pergolakan Politik Islam. Jakarta: Paramadina, 1996.

Barton, Gregory J. Modernisme Nurcholish Madjid, Djohan Effendi, Ahmad Wabib, dan Abdurrabman Wabid, trans. Nanang Tahqiq. Jakarta: Paramadina, Pustaka Antara, Yayasan Adikarya IKAPI, and The Ford Foundation, 1999.

Berger, Peter L. Langit Suci: Agama sebagai Realitas Sosial. Jakarta: LP3ES, 1991.

Effendy, Bakhtiar. "Demokrasi dan Agama: Eksistensi Agama dalam Politik Indonesia", in Komaruddin Hidayat and Ahmad Gaus AF (eds.), Islam, Negara, dan Civil Society. Jakarta: Paramadina, 2005.

Esposito, John L. Islam: the Straght Path. Oxford: Oxford University Press, 1988.

Fuady, Munir. Konsep Negara Demokrasi. Jakarta: Refika Aditama, 2010.

Geertz, Clifford. Kebudayaan dan Agama, trans. Francisco Budi Hardiman. Yogyakarta: Kanisius, 1992.

Hadziq. Islam dan Budaya Lokal: Belajar Memahami Realitas Agama dalam Masyarakat. Yogyakarta: TERAS, 2009.

Hakim, Lukman. "Kritik dan Apresiasi terhadap Peradaban Islam Nusantara", in Abdul Hakim and Latif, Yudi (eds.). Bayangbayang Fanatisme: Esai-esai untuk Mengenang Nurcholish Madjid. 
Jakarta Selatan: Universitas Paramadina and Pusat Studi Islam dan Kenegaraan, 2007.

Hidayatullah, Syarif. Intelektualisme dalam Perspektif Neo-Modernisme. Yogyakarta: Tiara Wacana, 2000.

HTI, Manifesto Hiøbut Tahrir. n.p.: Hizbut Tahrir Indonesia, 2009.

Interview Results Thursday, October 24, 2019 at 13:00 p.m.

Interview with Ameda on Thursday, November 15, 2019 at 11:30 a.m.

Interview with Avana on Wednesday, November 13, 2019 at 12:00 noon.

Interview with Haza, on Tuesday, 12 November 2019 at 10:00 a.m.

Interview with Irwi on Friday, October 18, 2019 at 13:30 p.m.

Latif, Yudi. Intelegensia Muslim dan Kuasa Geneologi Intelegensia Muslim Indonesia Abad ke-20. Bandung: Mizan, 2005.

Madjid, Nurcholish. Cendekiawan dan Religiusitas Masyarakat. Jakarta Selatan: Paramadina and Dian Rakyat, 2009.

-----. Islam: Doktrin dan Peradaban: Sebuah Telaah Kritis tentang Masalab Keimanan, Kemanusiaan, dan Kemodernan. Jakarta: Paramadina, 2000.

----. Pintu-pintu Menuju Tuban. Jakarta Selatan: Paramadina and Dian Rakyat, 2008.

Marty, Martin E. "What is Fundamentalism? Theological Perspective" in Kung and Moltmann (eds.), Fundamentalism as a Ecunemical Challenge. London: Rouledge, 1992.

Muthohirin, Nafi'. Fundamentalisme Islam: Gerakan dan Tipologi Pemikiran Aktivis Dakwah Kampus. Jakarta: IndoStrategi, 2014.

Palmer, Richard E. Hermeneutics. Evanston: Northwestern University Press, 1969.

PBAK observations in 2018/2019 on 09 to 16 August 2018.

Qodir, Zuly. Sosiologi Politik Islam: Kontestasi Islam Politik dan Demokrasi di Indonesia. Yogyakarta: Pustaka Pelajar, 2012.

Rahmat, M. Imdaddun. Arus Baru Islam Radikal: Transmisi Revivalisme Islam Timur Tengah ke Indonesia. Jakarta: Erlangga, 2009.

Results of an Interview with Vera on Friday, November 1, 2019 at 13:00 p.m.

Santosa, Khalid O. (ed.). "Sebuah Pengantar" in Mohammad Natsir, Islam Sebagai Dasar Negara. Bandung: Sega Arsy, 2004.

Sulaiman, Sadek Jawad. "Demokrasi dan Syura" in Wacana Islam Liberal: Pemikiran Islam Kontemporer tentang Isu-Isu Global. Jakarta: Paramadina, 2003. 
Iswahyudi, Udin Safala, Umi Kulsum

Syam, Nur. Madz̧hab-Madz̧ab Antropologi. Yogyakarta: LKiS and IAIN Sunan Ampel, 2009.

Ubaidillah, A. and Rozak, Abdul (eds.). Demokrasi, Hak Asasi Manusia, dan Masyarakat Madani. Jakarta: ICCE UIN Syarif, 2006. 